\title{
A Study on the Significance and Practice of Ideological and Political Theories Teaching in All Courses in Colleges and Universities
}

\author{
Ruochen Zhao ${ }^{1, *}$, Huichun Qiao ${ }^{1}$, Zhiqiang Yao $^{1}$ \\ ${ }^{1}$ Engineering Management Department, Inner Mongolia Honder College of Arts and Sciences, Hohhot, Inner \\ Mongolia, 010070, China \\ *Corresponding author. Email: 20201800230@imut.edu.cn
}

\begin{abstract}
It has always been a fine tradition of education in China to concentrate on moral education, pay attention to preaching, teaching and solving doubts, and the organic unity of educating people and talent education. The ideological and political course has great teaching responsibility, glorious mission and rich content. In this paper, the significance and teaching system of ideological and political theories teaching in all courses in colleges and universities are discussed, then its major issues are deeply analyzed, so as to strengthen education of college students to love the party, the country, socialism, the people, and collectives through ideological and political theories teaching in all courses, and guide college students to form the glorious mission of correct ideals and beliefs, political identity, family and country feelings, cultural literacy, constitutional awareness of the rule of law, and moral cultivation.
\end{abstract}

Keywords: Ideological and Political Theories Teaching in All Courses, Higher Education, Teaching Design, Teaching System

\section{INTRODUCTION}

The spirit of the national ideological and political conference in colleges and universities points out that the ideological and political work in colleges and universities is related to the fundamental question of what kind of people colleges and universities train, how to train people and for whom to train people. It is necessary to persist in taking the establishment of morality and cultivating people as the central link, carry out ideological and political work throughout the whole process of education and teaching ${ }^{[1-4]}$. realize the whole process of education and all-round education, and strive to create a new situation in the development of higher education in our country ${ }^{[5-7]}$. Ideological and political work is fundamentally the work of cultivating people's noble moral character, which must revolve around students, take care of students, serve students, and constantly improve students' ideological level, political consciousness, moral quality and cultural accomplishment, so that students can become talents with both ability and political integrity and all-round development ${ }^{[8-10]}$.

\section{CONCEPT OF IDEOLOGICAL AND POLITICAL THEORIES TEACHING IN ALL COURSES}

From the concept put forward, its purpose is to achieve all kinds of courses and ideological and political theory courses in the same direction, to achieve collaborative education. Whether it is "Sanquan" (Allmember education, whole-process education and all-round education) education or "Shiquan" education (Curriculum education, scientific research education, practical education, management education, organization education, service education, cultural education, network education, psychological education, subsidized education), it embodies the concept of cooperative education.

As the educational policy of our party and the common mission of all kinds of schools in our country, whether we can continuously train qualified builders and reliable successors for the cause of socialism with Chinese characteristics, whether Chinese Dream can gather, cultivate and transfer talents for realizing the great rejuvenation of the Chinese nation is the most 
important indicator to measure the educational level of a school. It is worth noting that world-class universities have grown up in the process of serving their own country. "as long as we make achievements and achievements in training socialist builders and successors, our universities will have a status and a say in the world."

\section{TEACHING SYSTEM OF IDEOLO-GICAL AND POLITICAL THEORIE-S TEACHING IN ALL COURSES}

According to the circular of the Ministry of Education on issuing the Guiding Outline of Ideological And Political Theories Teaching In All Courses in Colleges And Universities, colleges and universities should revise the talent training plan pertinently, earnestly implement the professional teaching standards in higher vocational schools, the national standards for the teaching quality of undergraduate majors, and the basic requirements for doctoral and master's degrees in first-tier disciplines and professional degrees, and build a scientific and reasonable teaching system of ideological and political theories teaching in all courses.

More importantly, we should adhere to the student-centered, output-oriented, continuous improvement, and constantly improve students' curriculum learning experience and learning effect.

\subsection{Public basic courses}

First of all, focus on building a number of courses to improve college students' ideological and moral cultivation, humanistic quality, scientific spirit, constitutional awareness of the rule of law, national security awareness and cognitive ability. Secondly, pay attention to imperceptibly strengthen students' ideals and beliefs, cultivate patriotism, strengthen moral cultivation, increase knowledge, cultivate the spirit of struggle, and improve the comprehensive quality of students. Then, create a number of distinctive sports and aesthetic education courses. The most important thing is to help students enjoy fun, strengthen their physique, improve their personality and temper their will in physical exercise, and improve their aesthetic accomplishment, edify their sentiments, moisten their hearts and stimulate creative vitality in aesthetic education.

\subsection{Professional education courses}

Specifically, according to the characteristics and advantages of different disciplines, we should deeply study the educational goals of different majors, deeply excavate and refine the ideological value and spiritual connotation contained in the professional knowledge system, and scientifically and rationally expand the breadth, depth and temperature of professional courses, and increase the knowledge and humanism of the courses from the perspectives of major, industry, country, international, culture and history, so as to enhance the leading, contemporary and open nature of the curriculum.

\subsection{Practical courses}

The professional experimental practice course should pay attention to the combination of learning and thinking, the unity of knowledge and practice, and enhance students' innovative spirit of exploration and practical ability to solve problems. The course of innovative entrepreneurship education should pay attention to enabling students to "dare to venture and be creative", and to enhance their innovative spirit, creative consciousness and entrepreneurial ability through personal participation. In addition, social practice courses should pay attention to educating and guiding students to carry forward the spirit of labor, combine "reading ten thousand books" with "traveling ten thousand miles", take root in China to understand the national conditions and people's conditions, and increase their wisdom and talents in practice. temper will and character in hard struggle.

\section{PRACTICE OF IDEOLOGICAL AND POLITICAL THEORIES TEACHING IN ALL COURSES}

\subsection{Pay attention to the guidance of ideas}

Under the guidance of Marxism College, special seminars on the joint work of ideological and political courses and ideological and political theories teaching in all courses at different levels should be organized to guide all kinds of subjects in the school, especially professional teachers, to fully understand the key role of ideological and political education. On the basis of running ideological and political courses, we should continue to promote other types of courses to play their educational function, promote ideological and political theories teaching in all courses in the same direction, and promote each other, so as to realize morality and cultivating people in the whole course teaching through the formation of a teaching system ideological and political theories teaching in all courses.

Furthermore, curriculum ideology and politics should be carried out, and all kinds of curriculum teachers should hold high the banner of Marxism and socialism with Chinese characteristics and adhere to the socialist direction of running a school. The first is to adhere to the fundamental position of $\mathrm{Xi}$ Jinping's thought of socialism with Chinese characteristics in the new era; the second is to adhere to the fundamental task 
of establishing morality and cultivating people; and the third is to persist in answering the fundamental question of "what kind of people to train, how to train people, and for whom to train people".

\subsection{Important role of teachers in the curriculum}

The theoretical advantages and leading role of ideological and political teachers should be brought into full play, gather the forces of all parties, and cultivate the ideological and political theories teaching in all courses. On the one hand, we should do a good job in the selection and recruitment of ideological and political teachers, so as to strengthen the communication between ideological and political teachers and professional teachers; on the other hand, ideological and political teachers should play a role in improving professional teachers' political awareness, political literacy and political level, so as to achieve full coverage of ideological and political theories teaching in all courses to the professional and curriculum connotation.

\subsection{Integration of elements of ideological and political theories teaching in all courses}

In order to promote the brainstorming, collective discussion and collective lesson preparation of the teaching team, the most appropriate ideological and political elements should be integrated into the curriculum content in the most appropriate way. Classroom discipline should be strict and classroom atmosphere should be active, so as to carry out double-tutor teaching. Furthermore, the leading role of ideological and political teachers, the leading role of professional teachers, and the main role of students themselves should be brought into play in diverse classroom teaching through multiple teaching methods such as project-based teaching, situational teaching, and immersive teaching. Finally, the goal of ideological and political theories teaching in all courses is realized in a silent way, As shown in Figure 1 and Figure 2.

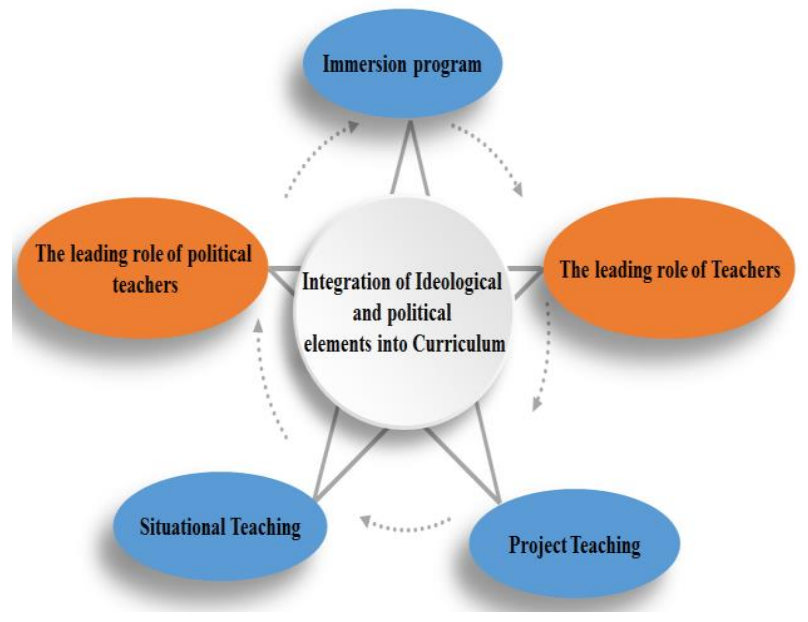

Figure 1 Integration of Ideological and political elements into Curriculum

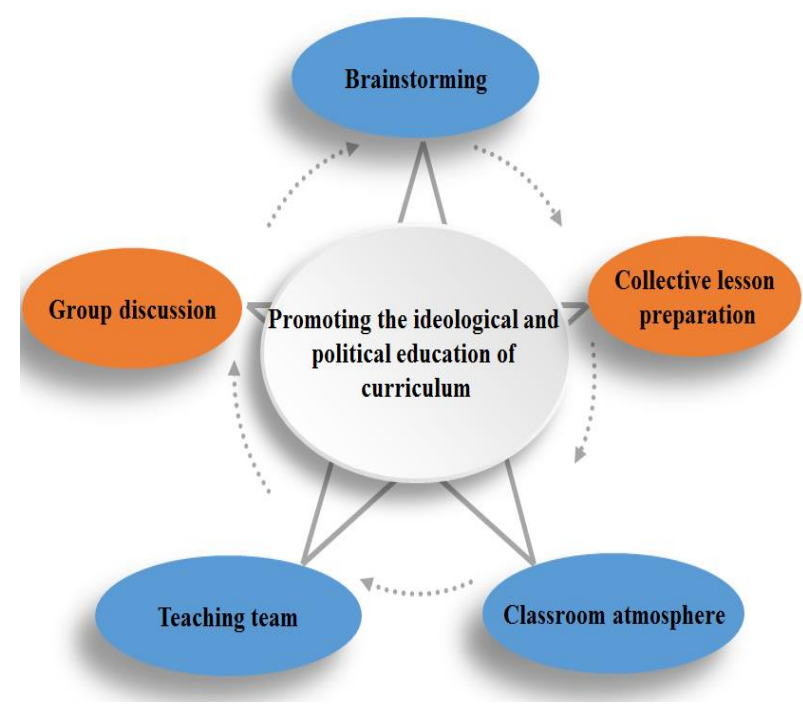

Figure 2: promoting curriculum thought and Politics

With the addition of ideological and political elements in the process of teaching, students should be guided to establish a correct outlook on life and values, apply what they have learned and serve the motherland. For example, in the process of introducing the brief history of the development and engineering application of engineering courses, a large number of engineering and technical examples from various countries in the world and our country are introduced. This comparison from ancient times to the present can enable students to understand the development of China's ancient civilization and the scientific and technological level of modern countries in the world.

\section{CONCLUSION}

To comprehensively promote the ideological and political theories teaching in all courses is to guide values in the teaching of knowledge and ability training, and to help students shape a correct world outlook, outlook on life and values, which is not only the due meaning of personnel training, but also the necessary content. This strategic move affects and even determines the issue of successors, the long-term stability of the country, as well as national rejuvenation and national rise. Therefore, it is necessary to firmly grasp the "main force" of teachers, the "main battlefield" of curriculum construction and the "main channel" of classroom teaching, so as to make all colleges and universities, all teachers and all courses bear the responsibility of educating people.

\section{AUTHORS' CONTRIBUTIONS}

Huichun Qiao contributed to the conception of the study;Ruochen Zhao contributed significantly to analysis and manuscript preparation; Zhiqiang Yao 
helped perform the analysis with constructive discussions.

\section{ACKNOWLEDGMENTS}

The authors would like to thank Inner Mongolia Honder College of Arts and Sciences for helpful discussions on topics related to this work. The authors would like to thank the editor and the reviewers for their useful feedback that improved this paper, and the anonymous reviewers for their helpful remarks.

\section{REFERENCES}

[1] Zhan, F.L. Exploration of Curriculum Ideology and Politics in Teaching Reform of Higher Education -A Case Study of Architectural Economics and Management Course [J]. Sichuan Architecture, 201,41(03):278-280.

[2] $\mathrm{Yu}$, K.C. The Connotation and Mechanism Cons -truction of Curriculum Ideology in the New E -ra [J]. Journal of Hebei Software Vocational a -nd Technical College,2021,23(02):49-53.

[3] Guo, L.Y. Research on the Reform of Teaching Methods of Ideological and Political Theory Courses in Colleges and Universities [J]. Journal of Jiamusi Vocational College, 201,37(07):9-10.

[4] Li H., Yu M.M. Research on Curriculum Id-eol ogy and Politics in Local Application-or-iented Universities: A Case Study of Tour- Guide Kn owledge and Business [J]. Journa-l of Sichuan University of Tourism,2021(04):93-95+100.

[5] Jing C. On the Enlightenment of Humanistic $\mathrm{Cu}$ -rriculum Theory to the Reform of Ideological and Political Theory Course in Colleges and U -niversities[J]. Scientific and Soci-al Research,2 021,3(1).

[6] Boqiao Cao, Cao Boqiao Research on the Appli cation of Computer Technology in the Innovati on and Development of ideology and politics E ducation Theory Courses in Universities[J] Jour nal of Physics: Conference Series, 2020, 1648 (2).

[7] Linfei Liang, Yao Lei Research on the Infiltrati on of Chinese Excellent Traditional Culture int o Ideological and Political Education in College $\mathrm{s}$ and Universities[J] Education Reform and De velopment, 2020, 2(2).

[8] Guo Jinming On the Integration of Excellent $\mathrm{Tr}$ aditional Culture and Ideological and Political Education in Colleges and Universities[J] Acade mic Journal of Humanities \& Social Sciences, 2021, 4(1).
[9] Zifu Liu Study on The Innovation of Ideologica 1 and Political Education in Colleges and Univ ersities Guided by Humanistic Care and Psycho logical Guidance[J] International Journal of Edu cation and Teaching Research, 2020, 1(4).

[10] Yeqin Lu Changes and Countermeasures of Ide ological and political education in Universities under the background of Internet[J] Learning \& Education, 2020, 9(4). 